\title{
ANALISIS PENGARUH RETURN ON ASSETS, DEBT TO EQUITY RATIO DAN RETURN ON EQUITY TERHADAP EARNINGS PER SHARE (STUDI EMPIRIS PADA PERUSAHAAN SEKTOR INDUSTRI DASAR DAN KIMIA YANG TERDAFTAR DI BEI PERIODE 2014-2018)
}

\author{
Sanny \\ Program Studi Magister Manajemen Universitas Tarumanagara \\ sannygbu@ymail.com
}

Masuk : 07-06-2020, revisi : 25-06-2020 diterima untuk diterbitkan : 25-06-2020

\begin{abstract}
This study aims to analyze the effect of return on assets, debt to equity ratio, and return on equity to earnings per share. This study took as many as 41 companies in the basic and chemical industry sectors listed on the Indonesia Stock Exchange in the 2014-2018 period determined by purposive sampling technique. Data analysis was performed using the robust least square (RLS) method. The results of the study prove that partially return on assets and return on equity have a significant effect on earnings per share, but the debt to equity ratio has not been able to provide a significant effect on earnings per share. This finding also proves that simultaneous return on assets, debt to equity ratio and return on equity have a significant effect on earnings per share.
\end{abstract}

Keywords: Return on Assets, Debt to Equity Ratio, Return on Equity, Earnings Per Share

\begin{abstract}
Abstrak: Penelitian ini bertujuan untuk menganalisis pengaruh return on assets, debt to equity ratio, dan return on equity terhadap earnings per share. Penelitian ini mengambil subjek yaitu sebanyak 41 perusahaan sektor industri dasar dan kimia yang terdaftar di Bursa Efek Indonesia dalam periode 2014-2018 yang ditentukan dengan teknik purposive sampling. Analisis data dilakukan dengan metode robust least square (RLS). Hasil penelitian membuktikan bahwa secara parsial return on assets dan return on equity berpengaruh signifikan terhadap earning per share, namun debt to equity ratio belum mampu memberikan pengaruh yang signifikan terhadan earnings per share. Temuan ini juga membuktikan bahwa secara simultan return on assets, debt to equity ratio dan return on equity berpengaruh signifikan terhadap earning per share.
\end{abstract}

Kata kunci: Return on Assets, Debt to Equity Ratio, Return on Equity, Earnings Per Share

\section{PENDAHULUAN}

Pasar modal menjadi salah satu instrumen dalam berinvestasi. Investasi adalah aktivitas penempatan dana yang dimiliki pada aset investasi dengan harapan memperoleh suatu keuntungan (Sijabat dan Suarjaya, 2018). Investasi didalam saham perusahaan publik tergolong investasi yang memiliki risiko tinggi. Para investor pada umumnya akan lebih memilih perusahaan yang memiliki kinerja yang baik dalam memutuskan untuk berinvestasi. Kegiatan investasi dapat dijadikan alternatif bagi wirausahawan yang tidak memiliki modal cukup di awal, dengan mengorbankan sebagian kekayaan yang seharusnya dapat dikonsumsi saat ini untuk ditanamakan di pasar modal namun di masa depan kekayaan yang dikorbankan tersebut akan memberikan pengembalian atau return yang dapat dijadikan modal suatu usaha (Dwialesi dan Darmayanti, 2016). Keuntungan dalam investasi saham diantaranya mendapat capital gain dan dividend yang dibagikan perusahaan. Harga saham menjadi salah satu ukuran dari keberhasilan perusahaan, ketika perusahaan memiliki saham yang memiliki harga tinggi dan nominalnya dari periode ke periode mengalami peningkatan maka mengindikasikan perusahaan yang memiliki kinerja yang baik, yang mana perusahaan tersebut dapat mengelola keuangan perusahaan secara produktif. 
Industri Dasar dan Kimia menjadi salah satu sektor yang menopang pertumbuhan sektor maufaktur, namun ada beberapa catatan dari industri semen seperti perang harga, untuk industri kertas dan kimia harga sudah mulai turun sejalan dengan ekonomi global yang melambat. Salah satu rasio saham yang menjadi indikator yaitu earning per share (EPS) yakni laba bersih setelah pajak dalam satu tahun fiskal dengan jumlah saham yang diterbitkan. Rasio EPS digunakan untuk mengukur keberhasilan manajemen dalam mencapai laba bagi pemilik perusahaan, Semakin tinggi nilai EPS, semakin besar laba dan kemungkinan meningkatkan jumlah dividen yang diterima oleh pemegang saham (Bratamanggala, 2018). Earnings per share sangat penting karena merupakan pendapatan bagi perusahaan untuk investor dan menjadi tolak ukur investor untuk menanamkan modalnya pada perusahaan (Diaz dan Jufrizen, 2014).

Pada praktiknya tidak semua perusahaan memiliki laba yang sesuai harapan perusahaan, ada beberapa perusahaan yang memiliki laba negatif sehingga mengakibatkan nilai earnings per share negatif. Melalui nilai laba bersih yang negatif ini membuat nilai earnings per share juga bernilai negatif. Hal ini tentunya ada faktor yang menjadi penyebabnya seperti rasio return on assets, return on equity maupun debt to equity ratio. Beberapa penelitian terdahulu menyebutkan bahwa ROA berpengaruh signifikan terhadap EPS (Bratamanggala, 2018). Penelitian lain juga memberikan bukti bahwa ROE berpengaruh signifikan terhadap EPS (Yunina, Nasir dan Syamni, 2017). Selanjutnya juga ditemukan bahwa DER memiliki pengaruh yang signifikan terhadap EPS (Bratamanggala, 2018). Hasil penelitian lain justru memberikan bukti sebaliknya yang mana ROA dan ROE tidak berpengaruh signifikan terhadap EPS (Diaz dan Jufrizen, 2014). Dalam penelitian (Nugroho dan Ichsan, 2011) juga disebutkan bahwa DER tidak berpengaruh signifikan terhadap EPS. Penelitian ini bertujuan untuk menganalisis pengaruh dari return on assets, debt to equity ratio dan return on equity terhadap earning per share di perusahaan Sektor Industri Dasar dan Kimia.

\section{TELAAH KEPUSTAKAAN}

\section{Earnings per share}

Earning per share (EPS), kadang-kadang disebut laba per saham dasar, adalah laba bersih per saham biasa yang beredar selama suatu periode (Waren et al., 2014). Earning per share adalah salah satu rasio keuangan paling terkenal di antara komunitas investasi (Brigham dan Ehrhardt, 2015). Earning Per Share merupakan rasio untuk mengukur keberhasilan manajemen dalam mencapai keuntungan bagi pemegang saham (Kasmir, 2017). Besarnya nilai EPS suatu perusahaan dapat dihitung berdasarkan informasi laporan neraca dan laporan laba rugi perusahaan. EPS sebagai informasi yang dianggap paling mendasar dan berguna karena bisa menggambarkan prospek earning di masa mendatang. Gambaran tersebut bisa menggambarkan prospek earning dimasa depan karena EPS dapat digunakan investor untuk mengetahui perbandingan antara nilai intrinsik saham perusahaan dibanding harga pasar saham perusahaan bersangkutan, dan atas dasar perbandingan tersebut investor bisa membuat keputusan apakah membeli atau menjual sahamnya.

\section{Return on Assets}

Return on asset merupakan perbandingan antara laba bersih dengan rata-rata total aktiva yang dimiliki perusahaan (Kieso et al.,2016). Return on asset sering juga disebut sebagai return on investment, karena ROA ini melihat sejauh mana investasi yang telah ditanamkan mampu memberikan pengembalian keuntungan sesuai dengan yang diharapkan dan investasi tersebut sebenarnya sama dengan aset perusahaan yang ditanamkan atau ditempatkan (Fahmi, 2014). Rasio yang menilai keefektifan perusahaan memperoleh untung dengan memaksimalkan asset miliknya (Sijabat dan Suarjaya, 2018). Return on asset adalah rasio keuangan perusahaan yang berhubungan dengan aspek earning atau profitabilitas. Return on asset yang tinggi menggambarkan keuntungan yang tinggi juga bagi pemegang saham dan membuat earning per share manjadi meningkat. Hal ini didukung dengan temuan sebelumnya yang menyebutkan 
bahwa ROA berpengaruh signifikan terhadap EPS (Bratamanggala, 2018; Yunina, Nasir dan Syamni, 2017). Dengan demikian dirumuskan hipotesis penelitian:

H1: Return on assets berpengaruh signifikan terhadap earnings per shares

\section{Debt to Equity Ratio}

Debt to equity ratio merupakan ukuran yang dipakai dalam menganalisis laporan keuangan untuk memperlihatkan besarnya jaminan yang tersedia untuk kreditor (Fahmi, 2014). Debt to equity ratio merupakan rasio yang digunakan untuk menilai utang dan ekuitas (Kasmir, 2017). Debt to equity ratio adalah perbandingan antara total hutang atau total debts dengan total sharehoder's equity (Horne dan Wachowicz, 2013). Pengukuran tingkat utang biasanya menggunakan debt ratio, debt to equity ratio, semakin tinggi rasio ini maka semakin besar pula jumlah utang yang digunakan dalam operasi perusahaan. Dengan kata lain, rasio ini berfungsi untuk mengetahui setiap rupiah modal sendiri yang dijadikan untuk jaminan utang. Rasio debt to equity dicari dengan cara membandingkan antara seluruh utang termasuk utang lancar dengan seluruh ekuitas. Semakin kecil rasio ini semakin baik. Hasil kajian penelitian terdahulu menyebutkan bahwa DER berpengaruh signifikan terhadap EPS (Bratamanggala, 2018; Briliyan, Dwiatmanto dan Yaningwati, 2013). Dengan demikian dirumuskan hipotesis penelitian:

H2: Debt to equity ratio berpengaruh signifikan terhadap earnings per shares Return on Equity

Return on equity merupakan rasio yang paling penting karena pemegang saham pasti menginginkan tingkat pengembalian yang tinggi atas modal yang mereka investasikan dan ROE menunjukkan tingkat yang mereka peroleh (Brigham dan Houston, 2015). Return on equity merupakan suatu pengukuran dari penghasilan (income) yang tersedia bagi para pemilik perusahaan baik (pemegang saham biasa maupun pemegang saham preferen) atas modal yang mereka diinvestasikan didalam perusahaan. Semakin tinggi return atas penghasilan yang diperoleh maka semakin baik kedudukan pemilik perusahaan (Syamsudin, 2004). Tingkat ROE memliki hubungan yang positif dengan harga saham, sehingga semakin besar ROE semakin besar pula harga pasar karena besarnya ROE memberikan indikasi bahwa pengembalian yang akan diterima investor akan tinggi sehingga investor akan tertarik untuk membeli saham tersebut dan hal ini menyebabkan harga pasar saham cenderung naik (Harahap, 2007). Hasil kajian penelitian terdahulu menyebutkan bahwa ROE berpengaruh signifikan terhadap EPS (Yunina, Nasir dan Syamni, 2017). Dengan demikian dirumuskan hipotesis penelitian:

H3: Return on equity berpengaruh signifikan terhadap earnings per shares berikut:

Berdasarkan uraian kaitan antar variabel di atas, maka model penelitian adalah sebagai

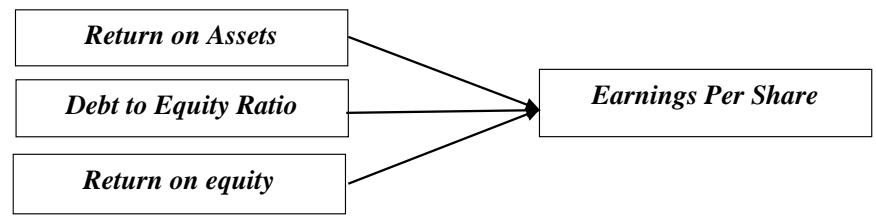

Gambar 1

Model Penelitian

\section{METODOLOGI PENELITIAN}

Desain penelitian ini adalah penelitian kuantitatif dengan desain kausalitas. Metode pengambilan sampel dalam penelitian ini adalah metode non-probability sampling yaitu purposive sampling sehingga diperoleh sebanyak 41 perusahaan perusahaan sektor industri dasar dan kimia dalam periode 2014-2018. Ada tiga variabel independen yaitu Return on Assets (X1), Debt to Equity Ratio (X2), Return on Equity (X3), kemudian satu variabel dependen yaitu Earnings per Share (Y). Data diperoleh melalui laporan keuangan setiap emiten dan diakses melalui laman Bursa Efek Indonesia. Data dianalisis dengan metode robust least square (RLS) dengan bantuan program Eviews versi 11. 


\section{Hasil Uji Statistik}

Analisis data dilakukan dengan robus least square yang mana dalam analisis ini memiliki tiga estimasi yang meliputi, M-Estimation, S-Estimation dan MM-Estimation. Dalam menentukan model estimasi terbaik, dapat dilakukan perbandingan nilai R Square masingmasing model, yang mana model estimasi dengan nilai $R$ Square dimiliki oleh S-ERstimation yaitu 0,407116 sehingga estimasi yang terbaik yaitu S- Estimation. Hasil analisis disajikan dalam tabel berikut.

\section{Tabel 2}

\section{Hasil Pengujian Hipotesis}

\begin{tabular}{lllll}
\hline Variable & Coefficient & z-Statistic & Prob. & Ket. \\
\hline \hline Return on Assets -> Earning per Share & 1.817181 & 5.284402 & 0.0000 & Diterima \\
Debt to Equity -> Earning per Share & 0.357993 & 0.484841 & 0.6278 & Ditolak \\
Return on Equity -> Earning per Share & 0.642938 & 4.624669 & 0.0000 & Diterima \\
\hline \hline
\end{tabular}

$* \mathrm{p}<0,05 ; * * \mathrm{p}<0,01$

Berdasarkan Tabel 2. dapat diketahui bahwa $\mathrm{H} 1$ dan $\mathrm{H} 3$ dinyatakan diterima, sedangkan $\mathrm{H} 2$ ditolak. Artinya, secara partial return on assets dan return on equity berpengaruh positif dan signifikan terhadap earning per share, sedangkan debt to equity ratio tidak memiliki pengaruh signifikan terhadap earnings per share. Sementara itu untuk melihat pengaruh secara simultan dicari dengan uji F sebagai berikut.

$$
F=\frac{\frac{\mathrm{R}^{2}}{\mathrm{k}}}{\frac{1-\mathrm{R}^{2}}{\mathrm{n}-\mathrm{k}-1}}
$$

Di mana nilai $R$ Square $\left(R^{2}\right)=0,407116$, kemudian jumlah data $(n)=205$ dan jumlah variabel bebas $(\mathrm{k})=3$ dihasilkan nilai $\mathrm{F}_{\text {hitung }}$ sebagai berikut.

$$
\mathrm{F}=\frac{0,407116 / 3}{(1-0,407116) /(205-3-1)}=\frac{0,1357}{0,0029}=46,7931
$$

Dengan demikian diperoleh nilai $\mathrm{F}$ hitung sebesar 46,7931 yang mana nilai tersebut akan dibandingkan dengan nilai $\mathrm{F}$ tabel, ketika nilai $\mathrm{F}$ hitung $>\mathrm{F}$ tabel maka secara simultan dinyatakan ada pengaruh yang signifikan. Nilai $\mathrm{F}$ tabel untuk $\mathrm{n}=205$ dan $\mathrm{k}=3$ yaitu 2,65. Dengan demikian terlihat bahwa nilai $\mathrm{F}$ hitung $>\mathrm{F}$ tabel, artinya return on assets, debt to equity ratio dan return on equity secara simultan berpengaruh signifikan terhadap earnings per share.

\section{DISKUSI}

\section{Return on Assets Terhadap Earnings per share}

Hasil analisis data diperoleh nilai Z statistik sebesar 5,284402 dengan probability yaitu 0,000 . Dengan melihat nilai probability $<0,05$ maka dinyatakan $\mathrm{H} 1$ ditetima. Temuan ini menjelaskan bahwa return on assets memiliki pengaruh yang signifikan terhadap earnings per share. Temuan ini menjelaskan bahwa return on assets dapat memberikan kontribusi signifikan pada perubahan earnings per share, ketika variabel return on assets mengalami peningkatan sebesar satu poin akan meningkatkan nilai earnings per share sebesar 1,817181 poin. Hasil penelitian ini sejalan dengan penelitian Bratamanggala (2018) yang membuktikan bahwa return on asset berpengaruh signifikan terhadap earnings per share. Return on assets mengukur tingkat pengembalian investasi yang telah dilakukan perusahaan dengan menggunakan seluruh aktiva yang dimilikinya. Semakin tinggi ROA yang dihasilkan perusahaan akan menjadikan investor tertarik akan nilai saham karena semakin tingginya keuntungan yang didistribusikan kepada pemegang saham.

\section{Debt to Equity Terhadap Earnings per share}

Hasil analisis data diperoleh nilai $\mathrm{Z}$ statistik sebesar 0,484841 dengan probability yaitu 0,6278 . Dengan melihat nilai probability $>0,05$ maka dinyatakan $\mathrm{H} 2$ ditolak. Temuan ini menjelaskan bahwa debt to equity tidak memiliki pengaruh yang signifikan terhadap earnings per share. Meskipun tidak signifikan, debt to equity dapat memberi sedikit kontribusi pada 
perubahan earnings per share, ketika variabel debt to equity mengalami peningkatan sebesar satu poin akan memberi perubahan pada nilai earnings per share sebesar 0,357993 poin saja. Hasil penelitian ini sejalan dengan penelitian yang dilakukan oleh Nugroho dan Ichsan (2011) yang telah membuktikan bahwa debt to equity ratio tidak berpengaruh signifikan terhadap earnings per share. Meskipun demikian, penelitian Bratamanggala (2018) justru memberikan temuan bahwa debt to equity ratio memiliki pengaruh signifikan terhadap earning per share. Perbandingan komposisi antara modal dan hutang harus tetap terjaga agar perusahaan tidak memiliki beban yang tinggi dalam membayar hutang. Dalam hal ini secara keseluruhan nilai debt to equity ratio memiliki rata-rata sebesar 1,47328 kali, hal ini lebih jauh dari batas maksimalnya sebagaimana disebutkan dalam Peraturan Menteri Keuangan Republik Indonesia Nomor 169/PMK.010/2015 tentang Penentuan Besarnya Perbandingan Antara Utang Dan Modal Perusahaan Untuk Keperluan Penghitungan Pajak Penghasilan. Besarnya perbandingan antara utang dan modal ditetapkan paling tinggi sebesar empat dibanding satu (4:1). Rasio DER masih dalam kategori sehat membuatnya tidak memberikan efek yang berarti pada rasio EPS.

Return on Equity Terhadap Earnings per share

Hasil analisis data diperoleh nilai Z statistik sebesar 4,624669 dengan probability yaitu 0,0000 . Dengan melihat nilai probability $<0,05$ maka dinyatakan H3 diterima. Temuan ini menjelaskan bahwa return on equity memiliki pengaruh yang signifikan terhadap earnings per share. Temuan ini menjelaskan bahwa return on equity dapat memberi kontribusi signifikan pada perubahan earnings per share, ketika variabel return on equity mengalami peningkatan sebesar satu poin akan meningkatkan nilai earnings per share sebesar 0,542938 poin. Sejalan dengan itu, Yunina, Nasir dan Syamni (2017) juga telah membuktikan bahwa return on equity berpengaruh signifikan terhadap earning per share, namun hasil penelitian ini justru tidak sejalan dengan penelitian Diaz dan Jufrizen (2014) yang menyatakan bahwa return on equity tidak berpengaruh signifikan terhadap earnings per share. Semakin besar ROE mencerminkan kemampuan perusahaan dalam menghasilkan keuntungan yang tinggi bagi pemegang saham. Untuk itu ketika perusahaan berhasil mendapatkan ROE yang tinggi maka akan semakin tinggi pula keuntungan yang didistribusikan kepada pemegang saham.

\section{Return on Assets, Debt to Equity dan Return on Equity Terhadap Earnings per share}

Hasil analisis diperoleh nilai $F$ hitung sebesar 46,7931 yang mana nilai tersebut lebih besar dari F tabel $(2,65)$ sehingga dinyatakan $\mathrm{H} 4$ dinyatakan diterima. Artinya return on assets, debt to equity ratio dan return on equity secara simultan berpengaruh signifikan terhadap earnings per share. Hal ini diperkuat dengan nilai $r$ square yang nilainya sebesar 0,407116, artinya variabel return on assets, debt to equity ratio dan return on equity hanya mampu menjelaskan variansi dari variabel earnings per share sebesar $40,7116 \%$ saja dan kontribusi dari variabel lain diluar model justru lebih besar yaitu 59,2884\%. Temuan ini sekaligus mengkonfirmasi baha faktor yang mempengaruhi earning per share tidak hanya ROA dan ROE saja, namun masih banyak faktor yang dapat menjadi satu ukuran dalam memprediksi nilai earning per share.

\section{KESIMPULAN DAN SARAN}

Hasil penelitian menunjukan bahwa secara partial return on assets dan return on equity berpengaruh positif dan signifikan terhadap earning per share, sedangkan debt to equity ratio tidak memiliki pengaruh signifikan terhadap earnings per share. Selanjutnya return on assets, debt to equity ratio dan return on equity secara simultan berpengaruh signifikan terhadap earnings per share. Penelitian ini hanya terbatas pada perusahaan Perusahaan Sektor Industri Dasar dan Kimia dengan periode selama 5 tahun yang mana memberikan hasil nilai $R$ Square sebesar 0,407116. Untuk itu bagi peneliti selanjutnya diharap dapat menyempurnakan model penelitian ini dengan menambahkan variabel prediktor lain yang mana hasil penelitian ini memperlihatkan bahwa kontribusi variabel lain diluar model masih besar. 


\section{DAFTAR RUJUKAN/PUSTAKA}

Bratamanggala. (2018). Factors Affecting earning per share: the case of Indonesia. International Journal of Economics and Business Administration, 6(2), 92-100.

Brigham, E. F., \& Ehrhardt, M. C. (2011). Financial Management Theory and Practice. USA: South Western Cengage Learning.

Brigham, E. F., \& Houston, J. F. (2015). Fundamentals of Financial Management. USA: South-Western Cengage Learning.

Briliyan, O. P., Dwiatmanto, \& Yaningwati, F. (2013). Pengaruh financial leverage terhadap earning per share (EPS) (Studi pada perusahaan industri otomotif dan komponen yang listing di BEI). Jurnal Administrasi Bisnis, 1(1), 95-103.

Diaz, R., \& Jufrizen. (2014). Pengaruh return on assets (ROA) dan return on equity (ROE) terhadap earning per share (EPS) pada perusahaan asuransi yang terdaftar di Bursa Efek Indonesia. Jurnal Manajemen dan Bisnis, 14(2), 127-134.

Dwialesi, J. B., \& Darmayanti, N. P. A. (2016). Pengaruh faktor-faktor fundamental terhadap return saham indeks Kompas 100. E-Jurnal Manajemen Unud, 5(4), 2544-2572.

Fahmi, I. (2014). Analisis Kinerja Keuangan. Bandung: Alfabeta.

Harahap, S. S. (2007). Analisis Kritis Atas Laporan Keuangan. Jakarta: Raja Grafindo Persada.

Horne V. J., \& Wachowicz, J. M. (2013). Prinsip-prinsip Manajemen Keuangan (Fundamental of Financial Management). Jakarta: Salemba Empat.

Kasmir. (2017). Analisis Laporan Keuangan. Jakarta: PT Rajagrafindo Persada.

Kieso, D. E., Weygandt, J. J., \& Warfield, T. D. (2016). Intermediate Accounting IFRS Edition. United States of America: John Wiley \& Sons.

Nugroho, H \& Ichsan, T. (2011). Pengaruh return on equity dan debt to equity ratio terhadap earning per share, studi kasus pada kelompok industri farmasi yang terdaftar di Bursa Efek Indonesia. Jurnal Ekonomi dan Bisnis, 10(1), 52-58.

Sijabat, F. D \& Suarjaya, A. A. G. (2018). Pengaruh DPR, DER, ROA dan ROE terhadap price earnings ratio pada perusahaan manufaktur. E-Jurnal Manajemen Unud, 7(7), 36813708.

Syamsudin, L. (2004). Manajemen Keuangan Perusahaan. Jakarta: PT Raja Grafindo Persada.

Waren, C. S., Reeve, J. M., \& Duchac, J. E. (2014). Financial and managerial Accounting. USA: South Western Cengage Learning.

Yunina., Nasir., \& Syamni, G. (2017). Pengaruh return on assets dan return on equity terhadap earning per share pada PT. Bank Muamalat Indonesia. 